УДК 351. 1

O. Р. Антонова,

к. держ. упр., дочент кафедри парламентаризму та політичного менеджменту,

Начіональна академія державного управління при Президентові Украӥни

ORCID iD: 0000-0002-6575-7915

DOI: $10.32702 / 2306-6814.2019 .8 .111$

КОНСТИТУЦІЙНО-ПРАВОВЕ

РЕГУАЮВАННЯ ШАЮБУ I СІМ'Ï В АМЕРИКАНСЬКИХ ТА АЗІАТСЬКИХ АЕРЖАВАX

\author{
O. Antonova, \\ candidate of Sciencesin Public Administration (PhD), assistant professor of Parliamentarism and Political \\ Management Department National Academy for Public Administration under the President of Ukraine
}

\title{
CONSTITUTIONAL AND LEGAL REGULATION OF BEAUTY AND FAMILY IN AMERICAN AND ASIAN STATES
}

Устатті досліджується проблема конституційно-правового регулювання шлюбу ісім 'ї в американських (на прикладі Канади) і азіатських (на прикладі Японії) країнах. Значну увагу приділено особливостям правової системи цих країн і характеру конституційних правовідносин громадян ушлюбі та сім'ї.

Інтерес до конституційно-правових систем Канади та Японії виник не випадково, адже історія державності цих країн та її правова система допомагає зрозуміти напрям сучасного розвитку основного осередку суспільства - сім'ї. Зокрема регулювання сімейних відносин в Канаді, незважаючи на їх приватний характер, в основному відбувається за нормами публічно-приватного права. Це пов'язано з особливостями правової системи Канади, зокрема демократичним характером конституційних норм, що містяться у 25 актах. Серед них і Канадська Хартія Прав і Свобод (декларація прав), яка складає першу частину Конституційного акту 1982 року, що регулює у тому числі шлюб і сім'ю.

Конституційно-правове регулювання шлюбу і сім 'ї в Японії здебільшого побудоване на національних звичаях і традиціях. Проте чинна Конституція Японії є Верховним законом Японії, яка детально регулює питання шлюбу. Характерним тутє закріплення рівноправності статей, взаємної згоди сторін на укладання шлюбу, проте бракує норм, що забезпечують рівність прав дітей. Тому можна стверджувально говорити, що японці володіють широким колом конституційних прав і свобод на шлюбі сім'ю, які носять публічно-приватний характер з елементами звичаєвого права.

The present stage of development of the national legal systems of the world testifies to the continuation of the trend towards their convergence and further mutual penetration. An important catalyst for this process is the awareness and recognition of the fundamental rights and freedoms of man and citizen for marriage and family. The form and extent of these constitutional rights in different countries have both general features and their peculiarities, which are determined by national traditions. In particular, issues that reveal the constitutional and legal regulation of marriage and family in American and Asian countries are relevant.

Therefore, the article deals with the problem of constitutional and legal regulation of marriage and family in American (on the example of Canada) and Asian (on the example of Japan) countries.

Interest in the constitutional and legal systems of these countries was not accidental, because the history of the state of these countries and its unique legal system, helps to understand the direction of modern development of the main center of society - the family.

However, modern scholars are disregarding this problem, which testifies to little research on the topic both at the domestic level and within international law.

Studies conducted in the article show that the constitutional and legal regulation of marriage and family in American and Asian countries is not identical. However, this does not indicate the truthfulness and falsehood of others.

Thus, the regulation of family relations in Canada, regardless of their private nature, is largely in the rules of public law. This is due to the peculiarities of the Canadian legal system, in particular the democratic 
nature of the constitutional norms contained in 25 acts. Among them is the Canadian Charter of Rights and Freedoms (the Declaration of Rights), which is the first part of the 1982 ConstitutionalAct governing marriage and family.

In general, the national characteristics of families living in American countries are traditionally perceived as the bulwark of a vibrant, vibrant society. Therefore, there are doubts among researchers about the fact that such families are a stable, unchanging institute. However, the stability of families, in our opinion, is not related to the democratic nature of their development. It depends on the amount of constitutional guarantees that ensure the strength of family relationships.

In particular, the Canadian unwritten Constitution is a fairly broad set of sources that adequately ensure the well-being of families. Moreover, these sources characterize historical maturity. These include laws, court precedents, separate acts of the head of state, legal practices, constitutional agreements, etc. (as opposed to the American Constitution as a holistic document).

Studies conducted in the article show that the constitutional and legal principles of marriage and family in Asia, in particular in Japan, have their own peculiarities. This is one of the Far Eastern legal systems characterized by the combination of its own traditional law and borrowed elements of the continental and Anglo-American families.

In the constitution of Japan, there is a noticeable influence of the Anglo-Saxon system of law, which is to consolidate a wide range of human rights and freedoms, especially personal, based on the concept of individualism. Consequently, the democratic features of the Constitution of 1947 include the provisions on "inviolability" of fundamental human rights, respect for the person, equality of all before the law, freedom of thought, conscience, religion, assembly, association, word, press. Significant progressive moment of this Constitution was the introduction in Japan of the formal equality of the spouses.

For Japan, as well as for some European states and states of America (England, France, USA), it is typical to avoid the legal definition of the concept of marriage, since according to the general legal concept, a marriage can be considered a civil contract (contract). Such a concept is based on the requirements of the law in order to conclude any contracts.

Typical for the Constitution of Japan is the consolidation of the equality of articles, the mutual consent of the parties to marry, but lacks the standards that ensure the equality of the rights of children. Therefore, it can be argued that the Japanese have a wide range of constitutional rights and freedoms for marriage and family, which are public-private with elements of customary law.

Ключові слова: шлюб, сім'я, публічно-приВатний характер Відносин, зъичаї, ріВність статей, взаємна згода сторін.

Key words: marriage, family, state-private nature of relations, customs, equality of the articles, mutual agreement of the parties.

\section{ПОСТАНОВКА ПРОБАЕМИ}

Сучасний етап розвитку національних правових систем світу засвідчує продовження тенденції до їх зближення та подальшого взаємного проникнення. Важливим каталізатором цього процесу є усвідомлення та визнання основоположних прав і свобод людини і громадянина на шлюб і сім'ю. Форма й обсяг цих конституційних прав у різних країнах мають як загальні риси, так і свої особливості, зумовлені національними традиціями. Зокрема актуальними є питання, що розкривають конституційно-правове регулювання шлюбу і сім'ї в американських та азіатських країнах.

Інтерес до конституційно-правових систем Канади та Японії виник не випадково, адже історія державності цих країн та її унікальна правова система, допомагає зрозуміти напрямок сучасного розвитку основного осередку суспільства - сім'ї.

\section{АНААІЗ ОСТАНHIX АОС ІАЖЕНЬ І ПУБ $А$ КАЦІЙ}

Серед науковців, що досліджують проблему конституційно-правового регулювання прав і свобод людини і громадянина, провідне місце займають представники сучасної вітчизняної наукової думки - 3. Габрелян [1], В. Кононенко, М. Перепьолкін, Т. Сироїд, І. Солопова
[4], Л. Тимченко [2], Л. Філяніна, О. Шаповалова [5] та інші.

Проте науковці оминають увагою проблему конституційно-правового регулювання шлюбу і сім'ї, що свідчить про малодослідженість теми як на рівні вітчизняного, так і в межах міжнародного права.

\section{META CTATTI}

Метою статті $€$ конституційно-правове регулювання шлюбу і сім'ї в американських (на прикладі Канади) та азіатських (на прикладі Японії) країнах.

\section{ВИК ААА ОСНОВНОГО МАТЕРІААУ АОСАIАЖЕННЯ}

Національні особливості сімей, що проживають у країнах Америки традиційно сприймаються як оплот вільного суспільства, що динамічно розвивається. Тому серед дослідників [1-5] з'являються сумніви відносно того, що такі сім'ї $є$ стабільним, незмінним інститутом. Проте стабільність сімей, на нашу думку, ніяк не пов'язана з демократичним характером їх розвитку. Вона залежить від обсягу конституційних гарантій, що забезпечують міцність сімейних відносин.

Зокрема канадська неписана Конституція являє собою досить широку сукупність джерел, що належним 
чином забезпечують добробут сімей. Більш того, ці джерела характеризує історична зрілість. До них належать закони, судові прецеденти, окремі акти глави держави, правові звичаї, конституційні угоди тощо (на відміну від американської конституції, як цілісного документу). Зокрема у Конституційному акті 1982 року визначено, що регулюють суспільні відносини в державі 25 основних актів. Крім того, параграф 52 (2) цього Конституційного акту визначає, що Канадська Хартія Прав і Свобод гарантує громадянам основні права і свободи, у тому числі право на шлюб і сім'ю.

Особливість реалізації цих прав полягають у тому, що, відповідно до Розділу 91 ч. 26 Конституції 1867 року (сьогодні цей закон $є$ одним із складових елементів Конституції Канади) - Парламент Канади, Федеральний уряд і провінції Канади мають виняткову владу щодо регулювання шлюбу і сім'ї. Зокрема, Парламент Канади має виключно законодавчі повноваження щодо регулювання шлюбу і сім'ї; Федеральний уряд виконує сутнісно-регулятивну функціюу цих правовідносинах; провінції Канади володіють виключною юрисдикцією щодо процедур реєстрації шлюбу та розлучення, регулюють питання власності подружжя і утримання членів сім'ї. Одночасно ч. 12 ст. 92 Конституції 1867 року надає законодавчим органам провінцій право приймати закони, що регулюють умови реєстрації шлюбу в урочистій обстановці.

У Конституції України все набагато простіше, адже традиційно, конституції романо-германської правової системи мають уніфрікований характер. Тому у ч. 1 ст. 51 Конституції України мова йдеться про загальні засади шлюбу, права та обов'язки подружжя: "Шлюб грунтується на вільній згоді жінки і чоловіка. Кожен із подружжя має рівні права і обов'язки у шлюбі та сім'ї" [6]. Щодо урочистої реєстрації шлюбу, то вона, відповідно доч. 2 ст. 22 Сімейного кодексу України, за заявою наречених, проводиться в урочистій обстановці [7].

Досягнення шлюбного віку $є$ першою умовою, що постає перед нареченими. Згідно з Конвенцією про згоду на укладання шлюбу, шлюбний вік та реєстрація шлюбу повинна відбутися між "чоловіком і жінкою, які досягли повноліття, мають право без будь-яких обмежень за ознаками раси, національності або релігії укладати шлюб та створювати сім'ю" [8].

У різних країнах вік повноліття коливається від 18 до 21 року. Наприклад, у канадському законодавстві зазначено, що для укладення шлюбу потрібно досягти 18 років [5], але в більшості країн, у супереч вимог Конвенції, шлюбний вік нижчий за вік повноліття. Наприклад, в Італії шлюбний вік для чоловіків становить 16 років, для жінок - 14, в Іспанії - 12 років як для чоловіків, так і для жінок. Найнижчим шлюбний вік у східно-азіатських країнах - він становить 9 років, а інколи він може бути ще й зменшено. Тобто нерідко подружжя, укладаючи шлюб, через низький вік навіть не усвідомлює значення своїх дій. Факт одруження для них - це результат угоди їхніх батьків. Зокрема в Індії, на початку двадцятого століття, зафіксовано більше ніж 600 наречених у віці від 1-го до 12-ти місяців (сьогодні, в Індії встановлені вікові обмеження у шлюбному віці: для чоловіків - 21 рік, а для жінок - 18 років) [9, с. 8].

Але практично у всіх країнах існують виключення для тих, кому ще не виповнився шлюбний вік. Аналіз законодавства Канади свідчить, що укласти шлюб з неповнолітніми (16-18 років) можна тільки за наявності письмового дозволу від обох батьків, законного опікуна або суду. Зокрема у ст. 373 Цивільного кодексу Квебеку (1994р.) визначено, що: "Перш ніж розпочати церемонію укладання шлюбу, відповідальна особа (службовець) встановлює осіб, вік та сімейний стан майбутнього подружжя. Службовець може здійснити церемонію укладання шлюб лише якщо майбутнє подружжя досягло хоча б шістнадцятиріччя, а у випадку їх неповноліття, він переконується в тому, що особа, яка наділена батьківською владою, або у відповідних випадках, опікун дав свою згоду на укладення шлюбу". При цьому, Загально федеральний Кримінальний кодекс (1955 р.) забороняє шлюб у віці до 16 років: "Всі, хто святкує, допомагає або бере участь в обряді або церемонії укладення шлюбу, знаючи, що особа, що вступає у шлюб, молодше 16 років, $є$ винним у вчиненні кримінального правопорушення і несе відповідальність у вигляді позбавлення волі на строк не більше п'яти років".

В Україні ж, право на шлюб надається "за заявою особи, яка досягла шістнадцяти років, за рішенням суду, якщо буде встановлено, що це відповідає її інтересам" (ст. 23 Сімейного кодексу України) [7]. Тобто згода батьків при цьому не потрібна. Порівняно з Канадою, в Україні, ранній вік неє злочином.

Отже, у різних країнах за наявності серйозних підстав, шлюбний вік може бути знижено. Право на зниження надається різними установами та посадовими особами. Так, в Україні право на шлюб надається лише судом, у Канаді державноюадміністрацією, у Німеччині опікунським судом, у Швейцарії - урядом кантону.

Не менш важливою конституційною умовою в укладанні шлюбу є його добровільність. У ч. 1 Цивільного кодексу Квебеку йдеться мова щодо вільної згоди та обізнаності двох осіб: "Кожен повинен надати добровільну згоду на укладення шлюбу". Крім того, кримінальним злочином у Канаді є допомога в проведенні весілля, якщо запрошені знають, що одного із подружжя змусили одружитися.

Вимога щодо вільної згоди наречених під час укладання шлюбу міститься і в ч. 1 ст. 51. Конституції України "Шлюб грунтується на вільній згоді жінки і чоловіка", адже якщо шлюб зареєстрований без вільної згоди жінки або чоловіка, то він визнається недійсним за рішенням суду [6]. Згода особи не вважається вільною, зокрема, тоді, коли в момент реєстрації шлюбу вона страждала тяжким психічним розладом, перебувала у стані алкогольного, наркотичного, токсичного сп'яніння, в результаті чого не усвідомлювала сповна значення своїх дій і (або) не могла керувати ними, або якщо шлюб було зареєстровано в результаті фрізичного чи психічного насильства (ст. 40 Сімейного кодексу України) [7]. Проте порушення цієї вимоги, як і попередньої щодо реєстрації шлюбу з неповнолітніми, не $є$ кримінальним злочином в Україні.

Кардинально відрізняє конституційне законодавство України від канадського умови гендерної приналежності.

У 1999 році, відповідно до рішення Верховного суду Канади, одностатеві пари в Канаді стали прирівнюватися до фрактичних шлюбів. Пізніше, федеральний уряд 
трьох провінцій надав одностатевим парам право на шлюб: в Онтаріо: Halpernet. al. v. Canada (Вищий суд Онтаріо, 12 липня 2002); в Квебеку: Хендрікс і Лебеф проти Квебека (Вищий суд Квебека, 6 вересня 2002, оскаржене апеляцією, відхиленої 19 березня 2004); в Британській Колумбії: Barbeau v. British Columbia 2003 ВССА 251 (Апеляційний суд Б. К., 1 травня 2003).

Ці рішення суду урегулювали правові відносини між подружжям в одностатевих парах. Таким чином, після 1985 року, у разі смерті одного із подружжя, інший отримав право на одноразову допомогу у зв'язку зі смертю годувальника.

У результаті зміни конституційних норм, у 2017 році кількість одностатевих пар у Канаді збільшилася на $60,7 \%$ порівняно з 2006 роком, що становить 0,9 відсотка від загального числа пар (72 880 одностатевих пар), близько $12 \%$ із яких живуть з дітьми. В Україні ж реєстрація шлюбу з особою, яка має таку ж саму гендерну приналежність, що і партнер, $є$ неконституційною. Адже Конституція України містить норми, в яких визначено, що шлюб - це союз "чоловіка і жінки" (ч.1. ст. 51) [6]

Конституційно-правові засади шлюбу і сім'ї в країнах Азії, зокрема в Японії, мають свої особливості, відмінні від країн Америки. Це одна з далекосхідних правових систем, що характеризується поєднанням власного традиційного права та запозичених елементів континентальної та англо-американської сімей.

Так, Конституція Японії 1947 року [10] замінила попередню Конституцію Великої Японської Імперії, що втратила чинність після поразки Японії у Другій світовій війні 1945 року. До цього часу жодних змін у діючу Конституцію Японії внесено не було.

У конституції простежується помітний вплив англосаксонської системи права, що полягає в закріпленні широкого кола прав і свобод людини, особливо особистих, заснованих на концепції індивідуалізму. Отже, до демократичних ознак Конституції 1947 р. [10] належать положення про "непорушність" основних прав людини, повагу особи, рівність усіх перед законом, свободу думки, совісті, віросповідання, зборів, об'єднань, слова, друку. Значним прогресивним моментом цієї Конституції стало введення в Японії формальної рівності подружжя. Адже Торговий кодекс визнавав жінок недієздатними в цивільному плані, позбавляв вдів права спадкоємства.

У результаті, з прийняттям нової Конституції, були повністю змінені існуючі раніше в японському суспільстві відносини у сім'ї. Зокрема ст. 24 Конституції Японії встановила, що: "Шлюб укладається тільки при взаємній згоді обох сторін і існує за умови взаємного співробітництва, в основу якого покладено рівність прав чоловіка і дружини" [10]. Таким чином, завдяки конституційним вимогам, скасовано інститут патріархальної сім'ї, жінка і чоловік почали визнаватися рівноправними учасниками сімейних відносин.

Проте реальність свідчить про присутність патріархальності в японському інституті сім'ї і сьогодні. Повагу до предків, підпорядкування старшинству $є$ невід'ємною частиною життя, молодші діти підпорядковуються старшим.

Що ж стосується майнових прав подружжя, спадщини, вибору місця проживання, розлучення та інших питань, пов'язаних з шлюбом і сім'єю, то такі відносини в Японії регулюються чинним сімейним законодавством, "виходячи з принципу особистої гідності і рівності статей" [10].

Отже, Конституції Японії містить лише одну статтю про шлюб і сім'ю. Вона перегукується зі ст. 51 Конституції України, де теж йдеться про добровільну згоду обох сторін, та рівні права і обов'язки у шлюбі, проте поняття "рівність" стосується як подружжя, так і дітей.

Щодо наявності конституційних прав дітей в Конституції Японії, то вона взагалі не згадує про "рівність" дітей, які народились поза шлюбом та у шлюбі. Таке замовчування цієї норми у японському праві розкриває непримиримість японців до позашлюбних дітей. Тобто відносна терпимість до незаконно народжених дітей пов'язана з національними звичаями, адже до прийняття чинної Конституції, незаконно народжені діти передавалися на виховання в сім'ю одного з батьків, що займали більш високий соціальний статус. Бездітним сім'ям із числа родичів, з метою продовження роду, надавалося право на усиновлення такої дитини без згоди їх батьків. За таких умов, діти набували всіх прав законно народжених.

Сьогодні спостерігаються нові проблеми, що стосуються народження дитини, демографрічних показників в державі, адже в Японії відсутня система соціальних гарантій для жінок під час вагітності та після пологів. Декретна відпустка здатна серйозно пошкодити кар'єру жінок. Ця соціальна несправедливість призвела до суттєвого зростання усвідомленої самотності, зниження кількості шлюбів та народжуваності дітей.

Для Японії, як і для деяких європейських держав та держав Америки (Англії, Франції, США), характерним $€$ уникнення законодавчого визначення поняття шлюбу, оскільки відповідно до загальної правової концепції шлюб може вважатися цивільно-правовою угодою (договором). Така концепція грунтується на вимогах, що ставляться законом до порядку укладення будь-яких договорів.

Все конституційно-правове регулювання сім'ї і шлюбу в Японії переважно носить звичаєвий характер. Тому усі суперечки між членами родини, вирішуються, в основному, без судового втручання. Наприклад $є$ усталеною практикою, коли перед укладанням шлюбу родини нареченого і нареченої звертаються до послуг посередника - "накодо", який добирає пари, виходячи із соціального статусу. Молоді обмінюються фотокартками і автобіографіями, після чого проходить церемонія заручення "юино", де сім'ї дарують одна одній дев'ять ритуальних подарунків - символів щастя.

Крім того, посередник вирішує всі питання, пов'язані з підготовкою весілля, і виступає свідком. Але його основним завданням $€$ урегулювання суперечок, що можуть виникнути між подружжям або між ними та їх сім'ями у продовж всього життя.

За японським законодавством до судової процедури розлучення вдаються лише у тих випадках, коли обидві сторони не можуть мирним шляхом розв'язати конфрлікт чи одностайно вирішити проблему. Якщо ж подружжя знаходять компроміс, вони вважаються розлученими без рішення суду, після того, як оформлять своє рішення офріційно. Майнові і немайнові суперечки про поділ майна, аліменти, батьківські права, після роз- 
лучення улагоджуються вже згаданим посередником, родичами і друзями колишнього подружжя. Адвокати не відіграють при цьому майже ніякої ролі.

Варто також відмітити, що протягом останніх 100 років Уряд Японії забороняв жінці упродовж шести місяців після розлучення знову виходити заміж. Ця давня архаїчна традиція ставила у безвихідне правове становище дітей, які народилися у "заборонений" шестимісячний період. Враховуючі міжнародні стандарти та прогресивну правову практику, у кінці 2017 року Верховний суд Японії визнав цей законодавчий підхід неконституційним [11], що дозволило виходити заміж після невдалого попереднього шлюбу вже через 100 днів. За умови, якщо ж на момент розлучення жінка не була вагітна іє медична довідка, яка це підтверджує, час очікування знімається зовсім.

Раніше подібні закони існували, наприклад, у Франції, Німеччині й Південній Кореї, але скрізь були скасовані як застарілі.

\section{ВИСНОВКИ 3 ПРОВЕАЕНОГО АОС ІАЖЕННЯ І ПЕРСПЕКТИВИ ПОАААЬШИХ РОЗВІАОК У ЦЬОМУ НАПРЯМ}

Здійснені у статті дослідження свідчать, що конституційно-правове регулювання шлюбу і сім'ї в американських і азіатських країнах не тотожнє. Однак це не свідчить про істинність одних і хибність інших.

Так, регулювання сімейних відносин у Канаді, незважаючи на їх приватний характер, в основному відбувається нормами публічно-приватного права. Це пов'язано з особливостями правової системи Канади, зокрема демократичним характером конституційних норм, що містяться у 25 актах. Серед них і Канадська Хартія Прав і Свобод [5] (декларація прав), яка складає першу частину Конституційного акту 1982 року, що регулює у тому числі шлюб і сім'ю.

Конституційно-правове регулювання шлюбу i сім'ї в Японії, здебільше побудоване на національних звичаях і традиціях. Проте діюча Конституція Японії є Верховним законом Японії, яка детально регулює питання шлюбу. Характерним тут є закріплення рівноправності статей, взаємної згоди сторін на укладання шлюбу, проте бракує норм, що забезпечують рівність прав дітей. Тому можна стверджувально говорити, що японці володіють широким колом конституційних прав і свобод на шлюб і сім'ю, які носять публічно-приватний характер з елементами звичаєвого права.

Література:

1. Габрелян 3.В. Суверенитет и права человека в условиях глобальной модернизации. Правоведение. 2013. - № 4. - С. 41-50.

2. Тимченко Л.Д. Міжнародне право: підручник. Київ: Знання, 2012. - 631 с.

3. Міжнародне право: словник-довідник / За заг. ред. д-ра юрид. наук, проф. Т.Л. Сироїд. - Харків: Юрайт, 2014. - 403 с.

4. Солопова І.В. Про співвідношення між міжнародним принципом дотримання прав людини і принципом невтручання у внутрішні справи держав. II Південно- український правничий часопис. - 2015. - № 2. С. $13-15$.

5. Шаповалова О.І. Сутність та типологія норм у міжнародних відносинах: аналіз з позицій концепції нормативної сили. Вісник Національного технічного університету України "Київський політехнічний інститут". Політологія. Соціологія. Право. - 2013. - № 2. - С. 28-35.

6. Конституція України від 28.06.1996 року. Відомості Верховної Ради України. 2014. №11. Ст. 4.

7. Сімейний кодекс України від 10.01.2002 року. № 2947-III. Відомості Верховної Ради України. - 2002. № 21-22. - Ст. 135.

8. Конвенция о согласии на вступление в брак, брачном возрасте и регистрации брака от 07.11.1962 г. URL: http://zakon2.rada.gov.ua/laws/show/995_242

9. Лаптева И.А. Легко ли быть супругой ... в детстве? НГ Религии. - 2007. - № 119. - С. 8.

10. Конституция Японии. Конституции государств (стран) мира. URL: http://worldconstitutions.ru /

11. Веб-сайт Верховного Суду Японії. URL: http:// www.courts.go.jp/saikosai/

References:

1. Gabrelyan, Z. V. (2013), "Sovereignty and human rights in the context of global modernization", Pravovedenye, vol. 4, pp. 41-50.

2. Timchenko, L. D. (2012), Mizhnarodne pravo [International law], Knowledge, Kyiv, Ukraine.

3. Siroyd, T. L. (2014), Mizhnarodne pravo: slovnykdovidnyk [International law: dictionary-directory], Yurayt, Kharkiv, Ukraine.

4. Solopova, I. V. (2015),"On the relationship between the international principle of observance of human rights and the principle of non-interference in the internal affairs of States", II Pivdennoukrains'kyj pravnychyj chasopys, vol. 2, pp. 13- 15 .

5. Shapovalova, O. I. (2013), "The essence and typology of norms in international relations: an analysis from the standpoint of the concept of normative force", Visnyk Natsional'noho tekhnichnoho universytetu Ukrainy "Kyivs'kyj politekhnichnyj instytut". Politolohiia. Sotsiolohiia. Pravo, vol. 2, pp. 28-35.

6 . The Verkhovna Rada of Ukraine (2014), "The Constitution of Ukraine of June 28, 1996", Vidomosti Verkhovnoi Rady Ukrainy, vol. 11, Art. 4.

7. The Verkhovna Rada of Ukraine (2002), "Family Code of Ukraine dated 10.01.2002", Vidomosti Verkhovnoi Rady Ukrainy, vol. 21-22, Art. 135.

8. The official site of Verkhovna Rada of Ukraine (2018), "Convention on consent to marriage, age of marriage and marriage registration of $07 / 11 / 1962$ ", available at: http://zakon2.rada.gov.ua/laws/show/ 995_242 (Accessed 15 Oct 2018).

9. Lapteva, I. A. (2007), "Is it easy to be a wife... in childhood?", NH Relyhyy, vol. 119. p. 8.

10. Site worldconstitution (2018), "Constitution of Japan", available at: http://worldconstitutions.ru/ (Accessed 15 Oct 2018).

11. The official site of Supreme Court of Japan (2018), available at: http://www.courts.go.jp/saikosai/ (Accessed 15 Oct 2018).

Стаття надійшла до редакчіӥ03.11.2018 p. 